\title{
Keragaman Genetik Beberapa Varietas Kentang (Solanum tuberosum L.) Berdasarkan Penanda Random Amplified Polimorphic DNA (RAPD) (Genetic Diversity of Several Varieties of Potato (Solanumtuberosum L) Based on Random Amplified Polymorphic DNA (RAPD))
}

\author{
Yefta B. Kawengian ${ }^{1)}$, E. Lengkong2)*, J. Mandang2) \\ 1) Program Studi Agronomi, Pasca Sarjana Universitas Sam Ratulangi Manado \\ 2) Jurusan Budidaya Fakultas Pertanian Universitas Sam Ratulangi Manado \\ *Email korespondensi: edylengkong@yahoo.com
}

Diterima 15 Agustus 2016, diterima untuk dipublikasikan 27 Agustus 2016

\begin{abstract}
Abstrak
Pengembangan tanaman kentang (Solanum tuberosum L.) unggul untuk menunjang kebutuhan produksi kentang yang terus meningkat membutuhkan tersedianya informasi genetik tanaman kentang yang ada. Informasi keragaman genetik dapat diperoleh menggunakan penanda molekuler RAPD yang dapat mendeteksi keragaman sampai pada tingkat DNA, baik pada daerah penyandi atau bukan penyandi protein dengan cara mendeteksi polimorfik sekuens nukleotida. Informasi yang diperoleh akurat karena tidak dipengaruhi lingkungan. Penelitian ini bertujuan untuk menganalisis keragaman genetik dari kentang kultivar Superjhon, Atlantik, Dessire, Nadia dan Granola menggunakan penanda RAPD. Hasil penelitian menunjukkan bahwa dari 14 primer acak yang digunakan hanya 7 yang memberikan pola pita DNA yang polimorfik dan 16 pita dari total 28 pita DNA yang dihasilkan (57\%) merupakan pita DNA polimorfik. Rata-rata keragaman genetik kentang sebesar 26,8 \%. Keragaman genetik terkecil $(15,4 \%)$ adalah antara kentang Atlantic dan Superjhon, sedangkan keragaman terbesar (57,7\%) antara kentang Nadia dan Dessire. Hasil analisis pengelompokan menunjukkan tanaman mengelompok berdasarkan sifat/karakter dan asalnya.

Kata kunci: kentang, keragaman genetik, RAPD
\end{abstract}

\section{Abstract}

The information of potato genetic diversity are required to support the increasing potato demands in the superior potato production. The information of genetic diversity can be obtained using RAPD molecular marker. RAPD can detect the genetic diversity at the DNA level, both in the coding region and non-proteincoding regions by detecting polymorphic sequences in nucleotides. This method provide accurate genetic information because it is not influenced by the environment. This study was conducted to analyze the genetic diversity of potato Superjhon, Atlantic, Dessire, Nadia and Granola using RAPD marker. Amongst the 14 random primers, only 7 primers produced polymorphic banding pattern. Sixteen DNA bands of total 28 existed DNA bands (57\%) were polymorphic. The average of genetic diversity was $26.8 \%$. The smallest genetic diversity (15.4\%) was between Atlantic and Superjhon, whereas the greatest genetic diversity (57.7\%) was between Nadia and Dessire. The analysis results showed that potato clustered grouping was based on their characters and their origins.

Keywords: genetic diversity, potatoes, RAPD 


\section{PENDAHULUAN}

Kentang (Solanum tuberosum penting dunia setelah gandum, beras dan jagung.Indonesia merupakan negara penghasil dan konsumen kentang terbesar di Asia Tenggara dengan luas pertanaman sekitar 76.291 ha dengan total produksi sebesar 1.347.817 atau rata-rata produktifitas 17, 67 ton/ha (DitjenHorti 2015). Pengembangan dan budidaya tanaman kentang terus meningkat seiring dengan tingginya permintaan kentang baik untuk konsumsi maupun industri olahan. Upaya pengembangan tanaman kentang hanya dapat dilakukan apabila tersedia informasi genetik yang memadai dari kultivar-kultivar yang ada saat ini, karena pengetahuan tentang keragaman genetik merupakan modal dasar bagi para ahli pemuliaan dan genetika populasi untuk pengembangan dan perbaikan tanaman.

Analisis keragaman suatu populasi tanaman dapat dilakukan baik secara morfologis yaitu dengan pengamatan langsung terhadap fenotipe tanaman atau juga melalui penggunaan penanda (marker) tertentu. Asiedu et al. (1989) menyatakan penanda adalah karakter yang dapat diturunkan yang berasosiasi dengan genotipe tertentu. Penanda dapat digolongkan atas penanda morfologis, sitologis atau yang terbaru penanda molekular (Melchinger 1990). Pendugaan variasi genetik menjadi semakin meningkat dengan adanya penanda yang didasarkan pada informasi tingkat DNA (Linch dan Milligan 1994).

Random Amplified Polymorphic DNA (RAPD) merupakan salah satu penanda molekular yang dapat digunakan untuk mendeteksi keragaman genetik pada tingkat DNA, baik pada daerah penyandi maupun bukan daerah penyandi protein dengan cara mendeteksi sekuens polimorfik dalam nukleotida. Penanda RAPD dapat memberikan informasi genetik yang akurat karena tidak dipengaruhi oleh lingkungan(Tingey et al. 1992). Penggunaan penanda RAPD untuk evaluasi keragaman genetik telah banyak dilaporkan antara lain oleh Lengkong (2001) untuk tanaman padi gogo; Guasmi et al. (2012) untuk tanaman barley; Abou-Talebet al. (2010), Rocha et al. (2010) dan Ghislainet al. (2006) untuk tanaman kentang; Bharti danVijaya (2013) untuk tanaman Terminalia bellirica dan Shivashankar (2014) untuk tanaman anti kanker.

\section{METODOLOGI PENELITIAN}

Penelitian ini dilakukan di Laboratorium Genetika, Pemuliaan Tanaman dan Biologi Molekular Sel Fakultas Pertanian Universitas Sam Ratulangi Manado bulanJuni-Juli 2016. Bahan tanaman merupakan planlet 5 kultivar kentang berumur 2 bulan yaitu Super jhon, Atlantik, Ganola, Dessiredan Nadia.

\section{Ekstraksi DNA}

DNA total sampel diekstraksi secara manual menggunakan metode CTAB dengan beberapa modifikasi. Sebanyak $2 \mathrm{ml}$ buffer ekstrak CTAB dimasukan dalam mortar yang telah berisi potongan sampel planlet kentang 0,2 gram. Setelah sampel dihancurkan, ekstraktan dipindahkan kedalam 2 tabung ependorf $1,5 \mathrm{ml}$ dan diinkubasi dalam air suhu $65^{\circ} \mathrm{C}$ selama 2 jam. Setelah didinginkan di sentrifugasi pada kecepatan 13.000 rpm selama 10 menit. Supernatan 
dipindahkan ketabung ependorf baru dan ditambahkan dengan chloroform isoamil alcohol, dihomogenkan dengan cara tabungnya dibolak balik secara perlahan dan kemudian disentrifugasi kembali selama 10 menit dengan kecepatan 13.000 rpm. Supernatan kembali dipindahkan ke tabung eppendorf baru dan ditambahkan $1 \mathrm{x}$ volume etanol absolute, setelah dihomogenkan, pellet DNA dikumpulkan dengan sentrifugasi $13.000 \mathrm{rpm}$ selama 10 menit. Seluruh cairan dalam tabung dibuang, kemudian pellet DNA dibilas dengan $70 \%$ etanol dan disentrifugasi 10.000 rpm selama 5 menit. Pelet DNA dikeringkan pada suhu kamar, selanjutnya diresuspensi dengan $50 \mu \mathrm{l}$ aquabides steril dan siap digunakan.

\section{Analisis RAPD}

Amplifikasi (penggandaan) DNA total sampel dilakukan menggunakan mesin PCR $T$ professional thermocycle (Biometra) dengan 14 jenis primer acakyang berasal dari kit A, B dan D (Operon Tehcnologies, Alameda, California), Adapun jenis primer yang digunakan dan nukleotida penyusunnya ditunjukkan padaTabel 1.

Campuran reaksi PCR yang dibuat untuk setiap penggandaan DNA sample sebanyak $25 \mu$ volume final yang terdiri atas primer acak, pure Tag Ready To Go PCR Beads (Amersham, Biosciences) dengan komposisi 2,5 unit DNA polymerase, dNTP(dATP, dCTP, dGTP, dTTP) masing-masing $200 \mu \mathrm{M}, 10 \mathrm{mM}$ Tris$\mathrm{HCl}, 50 \mathrm{mM} \mathrm{KCL}$ dan 1,5 mM $\mathrm{MgCl}_{2}$, DNA template $50 \mathrm{ng}$ dan air bebas ion steril. Amplifikasi DNA diatur dengan program PCR tahap I (pre PCR) $94^{\circ} \mathrm{C}$ 5 menit; tahap II, $94^{\circ} \mathrm{C} 1$ menit; tahap III, $37^{\circ} \mathrm{C} 30$ detik; tahap IV, $72^{\circ} \mathrm{C} 1$ menit, program tahap II-IV diulang sebanyak 30 kali dan tahap $\mathrm{V}, 72^{\circ} \mathrm{C}$ (post PCR). DNA hasil amplifikasi setelah ditambah dengan $5 \mu \mathrm{l}$ bromofenol blue [0.25 \% BB dan $40 \%$ $(\mathrm{w} / \mathrm{v})$ sukrosa] dielektroforesis pada gel agarose $1 \%$ yang mengandung etidium bromida $(0.5 \mu \mathrm{g} / \mathrm{ml})$. Pita DNA hasil amplifikasi diamati di atas transaluminator UV ( Hoefer), dan dilanjutkan dengan pemotretan camera digital (Nikon). Untuk menghindari kehilangan informasi hasil amplifikasi pita DNA pada gel agarose akibat lemahnya resolusi pita DNA maka dilakukan pemetaan kembali pita DNA tersebut di atas kertas milimeter blok.

\section{Analisis Data}

Informasi hasil pemotretan gel dan pemetaan pita DNA diinterpretasi datanya berdasarkan pita DNA yang terlihat sangat jelas maupun yang agak buram. setiap pita dianggap sebagai satu karakter, dan dinilai ' 1 ' bila ada pita dan ' 0 ' bila tidak ada pita. Pita DNA yang dinilai baik yang beresolusi tajam maupun lemah. Berdasarkan ada atau tidak adanya suatu pita, disusun matriks data biner, kemudian diturunkan matriks jarak kesamaan genetika antar individu tanaman dengan menggunakan koefisien kesamaan Jaccard dengan persamaan 


$$
S_{r s}=\frac{A}{A+B+C}
$$

$S_{\text {rs }}$ : Nilai kesamaan genetika antara individu $\mathbf{r}$ dan individu $\mathbf{s}$

A : Jumlah pita DNA yang terdapat baik pada individu $\mathbf{r}$ maupun individu $\mathbf{s}$

B : Jumlah pita DNA yang hanya terdapat pada individu $\mathbf{s}$

C : Jumlah pita DNA yang hanya terdapat pada individu $\mathbf{r}$

Tabel 1. Jenis Primer dan Urutan Nukleotida

\begin{tabular}{llllll}
\hline No. & Jenis Primer & UrutanNukleotida 5' $-3^{\prime}$ & No. & Jenis Primer & $\begin{array}{c}\text { UrutanNukleotida 5' - } \\
\text { 3' }\end{array}$ \\
\hline 1. & OPA-01 & CAGGCCCTTC & 8 & OPA-14 & TCTGTGCTGG \\
2. & OPA-03 & AGTCAGCCAC & 9. & OPB-03 & CATCCCCCTG \\
3. & OPA-05 & AGGGGTCTTG & 10. & OPB-06 & TGCTCTGCCC \\
4. & OPA-06 & GGTCCCTGAC & 11. & OPB-07 & GGTGACGCAG \\
5. & OPA-07 & GAAACGGGTG & 12. & OPB-08 & GTCCACACGG \\
6. & OPA-09 & GGGTAACGCC & 13. & OPB-19 & ACCCCCGAAG \\
7. & OPA-12 & TCGGCGATAG & 14. & OPD-20 & ACCCGGTCAC \\
\hline
\end{tabular}

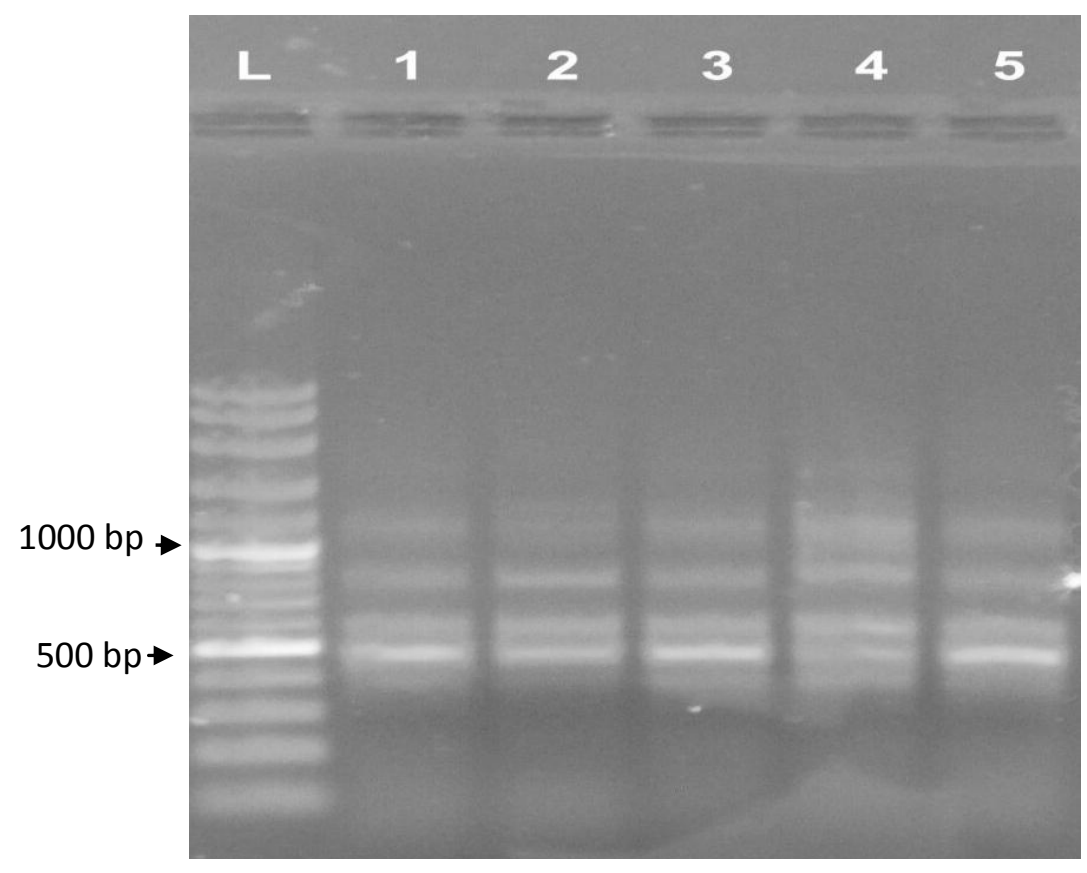

Gambar 1. Profil pita DNA yang diamplifikasidengan primer OPB-07. L DNA ladder 100 bp, 1. Superjhon, 2. Dessire, 3. Nadia, 4. Atlantikdan5. Granola

Data jarak genetika antar masing-masing individu ini selanjutnya digunakan untuk analisis pengelompokan secara sequential agglomerative, hierarchical and
nested
clustering menggunakan metode UPGMA (Unweighted pair-group method arithmetic) dan dibentuk dendrogram untuk melihat hubungan antar individu 
satu dengan yang lainnya. Keseluruhan analisis data ini dikerjakan melalui program komputer Numerical Taxonomy System (NTSYS-pc) versi 1.70.

\section{HASIL DAN PEMBAHASAN}

Hasil amplifikasi PCR pada seluruh sampel menggunakan 14 primer acak menunjukan tidak semua primer yang digunakan mampu dari total 28 pita DNA yang dihasilkan 16 pita (57\%) merupakan pita DNA polimorphic.Jumlah pita polimorphic yang berbeda-beda juga dihasilkan dan telah dilaporkan oleh beberapa peneliti antara lain Lima et al. (2002) menggunakan 25 primer pada analisis keragaman serangga Bemisiatabaci mendapatkan $55 \%$ pita polimorphic; Isaac et al. (2003) menggunakan 20 primer pada tanaman bunga matahari mendapatkan $70 \%$ pita polimorphic; Abou-Taleb et al. (2010)menggunakan 10 primer pada tanaman kentang mendapatkan $73 \%$ pita polimorphic.

Jumlah pita DNA polimorfis dalam analisis keragaman genetika sangat menentukan dalam penentuan tingkat keragaman suatu populasi, karena banyaknya pita DNA polimorfis akan lebih dapat mengambarkan keadaan genom tanaman dan akan memperkecil bias yang disebabkan tidak terwakilinya bagian-bagian genom (Nienhuis et al. 1994).Perbedaan jumlah dan polimorfisme pita DNA yang memberikan hasil amplifikasi berupa pola pita polymorphic. Dari 14 jenis primer acak yang digunakan hanya 7 (50 \%) yang memberikan pola pita polymorphic. Pada analisis RAPD pola pita monomorphic tidak menyumbang informasi untuk analisis keragaman. Jumlah pita DNA yang dihasilkan setiap primer antara 2-7 pita dengan ukuran 200-2000 bp,

dihasilkan oleh setiap primer menggambarkan kekompleksan dari genom tanaman yang diamati ( Grattapaglia et al. 1992), karena hasil amplifikasi pita DNA merupakan hasil berpasangannya sekuens primer dengan nukleotida penyusun DNA genom, sehingga makin beragam DNA genom akan menghasilkan semakin banyak dan kompleksnya pita DNA.

Pita DNA hasil amplifikasi memperlihatkan gradasi intensitas dan ketebalan yang berbeda-beda dari yang sangat tebal dan tegas sampai yang tipis dan buram. Adapun pola pita polimorpik yang dihasilkan oleh setiap primer terlihat pada Tabel 2.

Keragaman genetika dalam setiap kultivar kentang ditentukan berdasarkan hubungan kesamaan genetika antara seluruh sampel tanaman yang diteliti dengan cara membandingkan pita DNA dari setiap individu tanaman menggunakan koefisien kesamaan jarak Jaccard.

Tabel 2. Jenis Primer dan Jumlah Pita DNA yang Dihasilkan

\begin{tabular}{llccc}
\hline No. & Jenis Primer & Jumlah Pita & Pita Polimorphic & $\%$ \\
\hline 1. & OPA-05 & 4 & 3 & 75 \\
2. & OPA-12 & 4 & 3 & 75 \\
3. & OPA-19 & 3 & 1 & 33 \\
4. & OPB-03 & 4 & 2 & 50 \\
5. & OPB-07 & 7 & 4 & 57 \\
6. & OPB-19 & 4 & 2 & 50 \\
7. & OPD-20 & 2 & 1 & 50 \\
\hline Total & & 28 & 16 & 57 \\
\hline
\end{tabular}


Kawengian dkk., Keragaman .... 65

Tabel 3. Matrik Kesamaan Genetik Antara Tanaman Kentang

\begin{tabular}{llllll}
\hline & Superjhon & Dessire & Nadia & Atlantik & Granola \\
\hline Superjhon & 1.0000 & & & & \\
Dessire & 0.7037 & 1.0000 & & & \\
Nadia & 0.6539 & 0.5769 & 1.0000 & & \\
Atlantik & 0.8462 & 0.7692 & 0.7200 & 1.0000 & \\
Granola & 0.7777 & 0.7037 & 0.7917 & 0.7778 & 1.0000 \\
\hline
\end{tabular}

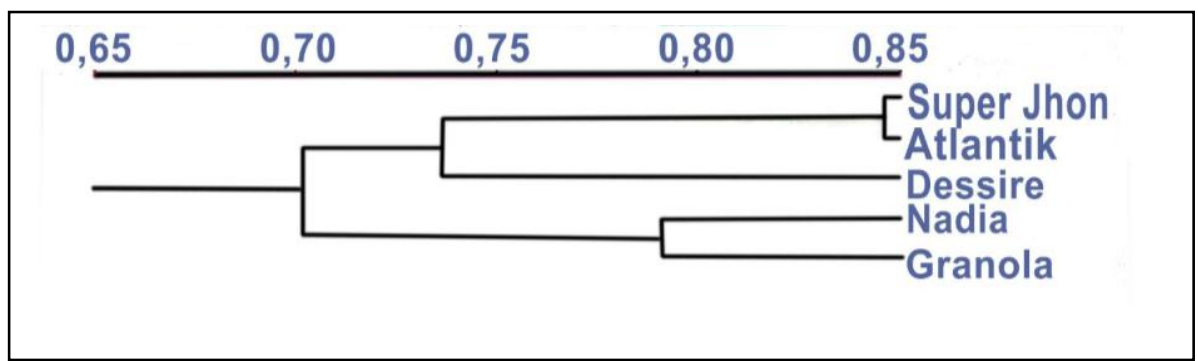

Gambar 2. Dendrogram beberapa varietas kentang

Berdasarkan data matriks kesamaan pada Tabel 3 ternyata ratarata kesamaan genetik dari seluruh tanaman sampel sebesar 73,2 \% atau keragaman genetik antar sampel sebesar 26,8 \%, dimana kesamaan genetik terbesar antara kentang Atlantik dan Superjhon yaitu sebesar $84,6 \%$ atau keragaman sebesar 15,4 $\%$ sedangkan kesamaan genetik terkecil antara kentang Nadia dan Dessire yaitu sebesar $57,7 \%$ atau keragaman genetik sebesar $42,3 \%$.

Analisis pengelompokan yang diturunkan dari matriks kesamaan memperlihatkan bahwa seluruh sampel terbagi atas 2 kelompok, kelompok I terdiri atas kentang Superjhon, Atlantik dan Dessire sedangkan kelompok 2 terdiri dari kentang Nadia dan Granola.

Hasil pengelompokan yang terlihat pada Gambar 2 menunjukkan beberapa varietas kentang di atas sangat sesuai dengan sifat dan asal kentang tersebut, seperti kentang Nadia merupakan kentang hasil mutasi alami dari kentang Granola yang terdapat dilokasi budidaya kentang Pangalengan, Jawa Barat dan pada tahun 2009 dilepas sebagai varietas baru kentang , kedua kentang ini termasuk pada golongan kentang sayur. Kentang Superjhon merupakan kentang hasil seleksi massa positip dari kentang Donata yang dilakukan oleh petani kentang di Modoinding Sulawesi Utara. Kentang Donata dan Atlantik merupakan 2 jenis kentang industri yang berdaging putih dan cocok diolah sebagai kentang goreng/kripik.

\section{KESIMPULAN}

Penanda RAPD mampu mengeksplorasi keragaman genetik kentang Superjhon,Atlantik, Dessire, nadia dan Granola. Berdasarkan hasil amplifikasi 7 primer yang menghasilkan pola pita DNA 
polimorphicdidapatkan rata-rata keragaman genetik tanaman kentang sebesar 26,8 \% Dimana keragaman genetic terkecil $(15,4)$ antara kentang Atlantic dan Superjhon, sedangkan keragaman terbesar $(57,7)$ antara kentang Nadia dan Dessire. Hasil analisis pengelompokan menunjukan tanaman mengelompok berdasarkan sifat/karakter dana salnya.

\section{DAFTAR PUSTAKA}

Abou-Taleb E, Aboshosha S, ElSherifE, El-Komy M (2010) Genetik diversity among late blight resistant andsusceptible potato genotypes. Saudi Journal of Biological Sciences 17: 133-138

Asiedu R, TerKuileN, .Mujeeb-KaziA (1989) Diagnostic marker in wheat wide crosses, dalam Mujeeb-Kazi and Sitch (1989) (eds.). Review Advances in Plant Biotechnology. International Symposium on GenetikManipulation in Crops. CYMMIT, Mexico.

Bharti S, Vijaya K (2013) Random amplified polymorphic DNA (RAPD) analysis for genetik diversity in Terminalia bellirica species (Roxb.), an important medicinal tree. Asian Journal of Plant Science and Research $3(4): 21-27$

Ditjen Horti (2015) Statistik Produksi Hortikultura Tahun 2014. Kementerian Pertanian Dirjen Horti 2015.

Ghislain M, Andrade D, Rodríguez F, Hijmans RJ, Spooner DM (2006) Genetik analysis of the cultivated potato SolanumtuberosumL. Phureja Group using RAPDs and nuclear SSRs Theor Appl Genet. 113:1515-1527
Grattapaglia D, Chaparro J, Wilcox P, McCord S, Werner D, Amerson $\mathrm{H}$, McKeand S, Bridgwater $F$,Whetten $R$, O'Malley $D$, Sederoff R (1992) Mapping in woody plants with RAPD markers: application to breeding in forestry and horticulture :3740.dalamApplication of RAPD Technology to Plant Breeding. Joint Plant Breeding symposia Series, Minneapolis, Minnesota.

Guasmi F, Elfalleh W, Hannachi $\mathrm{H}$, Fères K, Touil L, Marzougui N, Triki T,Ferchichi A (2012) The Use of ISSR and RAPD Markers for Genetik Diversity among South Tunisian Barley. International Scholarly Research Notices, ID 952196.

Isaacs SM, Manivannan N, Muralidharan V (2003) Genetikdiversity analysis using RAPD marker in inbred lines of sun flower (Helianthus annuusL.) Molekuler Ecology 3:91-99.

Lima LHC, Campos L, Moretzsohn MC, Návia D, de Oliveira MRV (2002) Genetik diversity of Bemisiatabaci (Genn.) Populations in Brazil revealed byRAPD markers. Genetiks and Molekuler Biology, 25, 2, 217-223

Nienhuis J, Tivang J, Skroch P (1994) Analysis of genetik relationship among genotypes based on molekuler marker data, p. 814. In Analysis of Malecular Marker Data. Joint Plant Breeding Symposia Series, Corvalis, Oregon 5-6 August 1992 . CSSA, Am Soc. Horticul. Sci., and Am. Genet. Assoc. 
Rocha EA, Paiva LV, de Carvalho HH, GuimarãesCT

Molekuler characterization and genetik diversity ofpotato cultivars using SSR and RAPD markers. Crop Breeding and Applied Biotechnology 10: 204210,

Shivashankar M (2014) Random Amplified Polymorphic DNA (RAPD) Markers in Anticancer Drug Plants. International Journal of Current
Microbiology and Applied Sciences. Vol.3: 1091-1101.

Tinggey, SV, Rafalski JA, Williams JGK (1992) Genetik analysis with RAPD markers :3-8. dalamApplication of RAPD technology to plant breeding. Joint Plant Breeding Symposia Series, Minneapolis, Minnesota. 1 Nov. 1992. CSSA, Am. Soc. Horticul. Sci., and Am. Genet. Assoc. 